\title{
SOCIAL PROCUREMENT: POLICY AND PRACTICE
}

\author{
Amy LudLOW*
}

\begin{abstract}
Public sector spending can be used to further social policy objectives, through social procurement. While the potential of social procurement has long been recognised, the scope for its lawful use in practice has been uncertain and contested. EU Member States have responded to these uncertainties in different ways, both at the level of policy and practice. This paper explores some of these divergences and uncertainties through two case studies of the implementation of Directive 2014/24/EU in the UK and the Netherlands. Through these case studies the nature of EU law and its operation and absorption within varied national contexts is reflected upon, as well as the prospects for social procurement following transposition of the new Directives.
\end{abstract}

Keywords: implementation of directives; public procurement; social policy and practice

\section{INTRODUCTION}

The public sector is the biggest single spender in the EU. ${ }^{1}$ How that money is spent makes a difference to the quality and cost of public goods, works and services. It can also make a difference to other policies, including human rights, ${ }^{2}$ environmental and social protection. By way of example, and since the focus of this article is upon social policy objectives, contracting authorities can require successful contractors

* Fellow and College Lecturer in Law, Gonville and Caius, University of Cambridge; and Affiliated Lecturer, Faculty of Law, University of Cambridge. I acknowledge with thanks the helpful guidance of Mijke Houwerzijl, Willem Janssen, Miriam Kullman, Imke Lintsen, Jo Mitchell, Willemijn Noordhoek, PIANOo, and Kim Schofaerts.

1 In its 'Public Procurement Strategy', the European Commission states that $18 \%$ of EU GDP is spent by public authorities: http://ec.europa.eu/growth/single-market/public-procurement/strategy/ index_en.htm.

2 The United Nations' Guiding Principles on Business and Human Rights name procurement policies as a tool for governments to encourage the protection of human rights by businesses. 
to pay their staff a living (rather than minimum) wage. They can prefer bids from companies that do not make use of insecure employment arrangements, such as zerohours contracts, or prefer bids that create job opportunities for people from socially disadvantaged groups, such as the long term unemployed.

The instrumental power of procurement has long been recognised by the European Union (EU) as well as EU Member States. ${ }^{3}$ As the European Commission put it in its Buying Social guidance of 2010:

'Socially responsible public procurement is about setting an example and influencing the market-place. By purchasing wisely, public authorities can promote employment opportunities, decent work, social inclusion, accessibility, design for all, ethical trade, and seek to achieve wider compliance with social standards. ${ }^{4}$

While the power of the public purse has long been recognised, the scope for its lawful use in practice, especially in the field of social policy, has been uncertain and contested. The EU institutions, especially the Commission, have feared that Member States might misuse any social procurement discretion to favour national businesses. This risk may seem especially heightened during periods of financial crisis when public attention is turned even more sharply to the prosperity of national businesses and national workers. ${ }^{5}$ Such national protectionism would breach the general EU law principle of non-discrimination upon which shared European growth and success is premised.

In consequence of these fears, the EU institutions generally have taken narrow views about the meaning of value for money and about how closely connected social policy or other benefits must be to the good or service that is being procured. ${ }^{6}$ The dominant view among the EU institutions has been that 'labour and social standards flow from economic development but do not generally contribute to it'. 'This view has made it difficult, for example, to justify a contracting authority's decision to favour a tender for the provision of office furniture from a company that pays its staff a living wage over a company that pays only the national minimum wage. This is because staff pay is unlikely to alter the characteristics or performance of the product; the

$3 \quad$ See generally C. McCrudden, Buying Social Justice: Equality, Government Procurement and Legal Change (Oxford: OUP, 2007).

4 Buying Social: A Guide to Taking Account of Social Considerations in Public Procurement, SEC (2010) 1258, p.5.

5 This is reflected in the Commission's memo 'Revision of public procurement Directives - frequently asked questions' 15 January 2014 - 'procurement markets must be kept on Union-wide (all the more in times of financial crisis)': http://europa.eu/rapid/press-release_MEMO-14-20_en.htm.

6 For detailed analysis see A. Ludlow, Privatising Public Prisons: Labour Law and the Public Procurement Process (Oxford: Hart, 2015), pp.106-141.

7 H. Kountouros, “Quality at Work” after the Lisbon Strategy: is there a future?' in M. A. Moreau (ed.), Before and After the Economic Crisis: What Implications for the European Social Model? (Cheltenham: Edward Elgar Publishing, 2011), p.60. 
social policy objective cannot easily be assigned a direct, objective and economic value.

There have been interesting divergences in how EU Member States have responded to these legal uncertainties, both at the level of policy and practice. ${ }^{8}$ Some Member States have been more ambitious in their social procurement than others. Scottish guidance, for example, is bolder than its Westminster counterpart. There is a perception that some Member States take the procurement rules 'less seriously' than others, in ways that enable national industries to be supported. ${ }^{9}$ In the wake of the British government's decision to award the Thameslink train contract to German company, Siemens, rather than to the British company, Bombadier, the then Secretary of State for Transport, Phillip Hammond, said:

'I firmly believe that free trade and open markets are the best way for us to proceed, but $[\ldots]$ there is a case for looking at the way in which some of our neighbours and competitors operate the EU procurement Directive, because it seems quite astonishing that [...] they have managed to achieve very high percentage penetrations of French-built trains on the French railway and of German-built trains on the German railway.' ${ }^{10}$

There have been few empirical studies of public procurement processes in practice; fewer still with a focus on social procurement. ${ }^{11}$ This means that it is difficult to determine whether policy differences are merely rhetorical or whether they produce divergent procurement processes and outcomes. Notwithstanding this dearth of empirical evidence, the public procurement rules were identified by the Commission in its Single Market Act I of April 2011 as one of 12 policy 'levers' in need of reform to enable the EU's internal market to realise its full potential. Despite attempts at simplification and modernisation in the 2004 public procurement Directives, crossborder procurement has remained low. ${ }^{12}$ Reform was said to be required to improve

8 As to variations in practice see, e.g., Landmark Project 'Success Stories in Socially Responsible Public Procurement' (2014): www.landmark-project.eu/fileadmin/files/en/LANDMARK_Success_ Stories_2014_-_eng.pdf.

9 This perception is not necessarily supported by data on case volume, respondent country or nature of breach in infringement proceedings brought by the Commission against Member States for breaches of the procurement rules. See, further, http://ec.europa.eu/internal_market/scoreboard/ archives/2014/07/performance_by_governance_tool/infringements/index_en.htm\#maincontentSec4.

10 L. Maer, 'Public procurement' (2012) Economic Policy and Statistics Section, House of Commons Library Note SN/EP/6029, p.6.

11 Though see W. Kahlenborn et al 'Strategic use of public procurement in Europe: final report to the European Commission’ MARKT/2010/02/C (2011): http://ec.europa.eu/internal_market/ publicprocurement/docs/modernising_rules/strategic-use-public-procurement-europe_en.pdf.

See also Ludlow, above, n.7 and forthcoming work by R. Craven funded by the British Academy/ Leverhulme.

12 Analysis in 2011 by the Commission of average distances between buyers and sellers confirms that relatively small geographical distances are typical in public procurement. 'The average distance between purchaser and supplier is $102 \mathrm{~km}$ for works contracts, $123 \mathrm{~km}$ for services and $232 \mathrm{~km}$ for supplies.' European Commission Internal Market and Services, 'EU public procurement legislation: 
this, as well as to bolster the role of public procurement in helping the EU to develop 'a Single Market which is greener, more social and more supportive of innovation'. ${ }^{3}$ The Commission also highlighted the potential of public procurement to 'drive key EU2020 horizontal policies, such as those aimed at creating a more innovative, green and socially-inclusive economy.' ${ }^{14}$

In December 2011 the Commission seized the legislative nettle and new public procurement Directives have resulted: Directive 2014/23/EU on concession contracts, 2014/24/EU on general public procurement and 2014/25/EU on utilities procurement. The new Directives entered force on 17 April 2014 and Member States have until 18 April 2016 to transpose them into domestic law. ${ }^{15}$ Commissioner Michel Barnier described the new procurement rules as having three main objectives: 'simplification, flexibility and legal certainty'. ${ }^{16}$ Social policy was given greater prominence in the European Parliament's negotiating position and its press release about the intended effects of reform. The headline of the Parliament's press release of 14 January 2014 read:

'New EU-rules on public procurement will ensure better quality and value for money when public authorities buy works, goods or services, thanks to new award criteria which will put more emphasis on quality, environmental considerations, social aspects and innovation. The new rules will also make it easier for small and medium-sized firms to bid and include tougher rules on subcontracting. ${ }^{17}$

Catherine Barnard has published a detailed analysis of the scope for Commissioners to take account of social policy within the new general public procurement Directive. ${ }^{18}$ Although the doctrinal analysis is complex, Barnard describes five key reforms that lead her to conclude that 'the Directive provides the green light for social creativity in procurement and a strong indication that the EU - and the European Commission in particular - far from being a threat will in fact be supportive or targeted social initiatives.' ${ }^{19}$

delivering results. Summary of evaluation report' (2011), p.16: http://ec.europa.eu/internal_market/ publicprocurement/docs/modernising_rules/executive-summary_en.pdf.

13 Communication from the Commission to the European Parliament, the Council, the Economic and Social Committee and the Committee of the Regions, 'Single Market Act: twelve levers to boost growth and strengthen confidence', COM (2011) 206, Brussels, 13.04.2011, p.19.

14 Http://ec.europa.eu/growth/single-market/public-procurement/strategy/index_en.htm.

15 The transposition deadline for the provisions on e-procurement is 18 October 2018.

16 MEMO/14/18, 15 January 2010: http://europa.eu/rapid/press-release_MEMO-14-18_en.htm.

17 Www.europarl.europa.eu/news/en/news-room/content/20140110BKG32432/html/New-EU-ruleson-public-procurement-ensuring-better-value-for-money.

18 C. Barnard, 'To Boldly Go: Social Clauses in Public Procurement' (forthcoming). See, more generally on the new Directives, F. Lichere, R. Caranta and S. Treumer (eds.) Modernising Public Procurement: The New Directive (DJOF Publishing, 2014).

Barnard, above, n.19, pp.23-24. 
Notwithstanding the importance of these doctrinal developments, there is often a gap between law 'on the books' and law in practice, especially in fields as complex as public procurement, where mostly public sector clients do not have the resources to afford detailed or sophisticated legal advice as clients in cognate fields, such as competition law. Moreover, inherent in the use of Directives as instruments of EU law harmonisation, is space for Member State discretion. Processes of transposing Directives into Member State law are varied, nuanced and generally underresearched. ${ }^{20}$ There is evidence that Member States have taken diverse approaches to the regulation of public procurement, despite longstanding EU-led harmonisation. ${ }^{21}$

The focus of this paper is upon how Member States are engaging with the new procurement Directives. More particularly, this paper explores the scope Member States perceive for furthering social policy objectives within the rules, including how that might be different to the discretion that existed within the 2004 Directives, understandings which we know (from pan-European surveys) vary between Member States. $^{22}$

To these ends this paper explores social procurement policy and practice in two Member States: the Netherlands and the United Kingdom. The data that inform the analysis have been obtained from a combination of publicly available documentary sources (written in English or translated), alongside discussions with policymakers, practitioners, businesses and academics in the relevant EU Member States. The highly specialised nature of procurement law, alongside the sensitivities of asking probing questions at a time of legal change, have not made data access straightforward. Section 3 draws together the analysis from the Netherlands and the UK to reflect upon what might be the overall social policy potential and effects of the new public procurement rules. This section highlights areas of consensus and difficulty in social procurement, alongside some differences in procurement policy and practice. The paper concludes by offering broader reflections about what these small procurement 'case studies' might tell us about the nature and operation of EU law at national level.

$20 \quad$ Though see Hart's 'EU Law in the Member States' series, which is shedding helpful light upon EU law as it is experienced and operated within the Member States. See, e.g., M. Freedland and J. Prassl (eds.) Viking, Laval and Beyond (Oxford: Hart, 2015).

21 A useful general comparative survey is provided by T. Bianchi and V. Guidi (eds.) 'The Comparative Survey on the National Public Procurement Systems Across the PPN', December 2010: www.ppneurope.org/docs/ItalianPresidency/Comparative\%20survey\%20on\%20PP\%20systems $\% 20$ across\%20PPN.pdf.

22 See e.g. W. Kahlenborn et al 'Strategic Use of Public Procurement in Europe' (2011) final report to the European commission MARKT/2010/02/C, p.IX-XII. 


\section{POLICY AND PRACTICE}

\subsection{The Netherlands}

\subsubsection{Overview of Sources and Legislation}

The procurement market in the Netherlands is said to be worth $€ 60$ billion per year. ${ }^{23}$ According to OECD data the Netherlands spent over $20.8 \%$ of its Gross Domestic Product (GDP) on public procurement transactions in 2013; 44\% of total Dutch government expenditure and the highest procurement spend of any of the OECD countries. ${ }^{24}$ Though procurement spend remains high in the Netherlands, Van de Meent and Manunza report an increase since 2010 in the number of intrapublic sector collaborations for the provision of public services (rather than publicprivate arrangements). ${ }^{25}$ According to Van de Meent and Manunza this increase in internalisation can be explained 'by a growing belief that market performance, and competition, are not always able to provide the desired outcome for certain services. ${ }^{26}$ There is some evidence in the current Dutch government's coalition agreement that internalisation has been motivated partly by a desire to improve terms and conditions of employment in some of the most precarious sectors of the labour market. ${ }^{27}$ Since October 2012, Dutch municipalities have been exempted from the obligation to tender for social support service contracts, most notably for elderly and disabled persons. ${ }^{28}$

Responsibility for public procurement law and policy sits within the Department of Economic Affairs. The Netherlands Enterprise Agency (Rijksdienst voor Ondernemend Nederland) also provides information about sustainable procurement. ${ }^{29}$ Generally though, procurement in the Netherlands is highly decentralised. Breaches of the

23 Stichting Onderzoek Multinationale Ondernemingen (SOMO) 'A Review of Dutch Policy for Socially Responsible Public Procurement', March 2014, p.1.

24 Www.oecd-ilibrary.org/docserver/download/4211011ec046.pdf?expires=1454315718\&id=id\&accn ame=guest\&checksum=B9FD9206E76A6E478C44C3B018AA848E.

25 Visienota 'Bestuur en Bestuurlijke inrichting', 10 November 2011.

26 G. van de Meent and E. Manna (ed.), 'The Netherlands' National report (XXVI FIDE Congress, Topic 3, The Netherlands), May 2014, p.4. See also W. Janssen 'Public Procurement Law and InHouse Delivery of Public Services: Improving a Paradox' in A. McCann et al (eds.) When Private Actors Contribute to Public Interests: A Law and Governance Perspective (The Hague: Eleven Publishing, 2014), pp.7-26.

27 Www.europeancleaningjournal.com/magazine/articles/european-reports/surprising-purchasingpolicy-in-the-netherlands.

28 See Wijziging van de i.v.m. de kwaliteit van de huishoudelijke verzorging, de kwaliteit van de maatschappelijke ondersteuning en i.v.m bekostiging van het gemeentelijk beleid [Alteration of the Social Support Act], Stb. 2012, 310. This exemption was a legislative initiative of the Socialist Party. The Government opposed it on the ground that it breaches the procurement rules in Directive 2004/18. The Commission issued an unofficial opinion on 8 April 2010 that concurred with the Government's view. See further Parliamentary Papers II 2009/10, 31 353, No. 10. 
procurement rules are mostly dealt with by national civil courts, ${ }^{30}$ but tenderers can also submit complaints to the National Public Procurement Expert Commission (Commissie van Aanbestedingsexperts) for informal resolution.

In 2005, PIANOo, the Dutch Public Procurement Expertise Centre, was created. PIANOo sits within the Ministry of Economic Affairs and was created to professionalise procurement processes: to improve efficiency and legal compliance by providing information and sharing expertise. PIANOo also administers TenderNed, the Dutch online tendering system. ${ }^{31}$ Another important actor in the field of social procurement, is SOMO; an organisation that supports the implementation of sustainable and ethical procurement policies. ${ }^{32}$

The Dutch government took a 'copy out' approach to implementing the 2004 public procurement Directives, by way of a framework law with two Decrees for 2004/17/EC and 2004/18/EC and a separate law to implement the remedies of Directive 2007/66/ EC. ${ }^{33}$ No additional national legislation was adopted to cover public contracts worth less than the EU thresholds. Prior to 2005, the Netherlands chose to implement the Directives by simple reference, such that there was no national legislative text. ${ }^{34}$ Concerns about collusion and bid-rigging, particularly in the construction sector following whistleblowing in 2001, prompted calls for reform to increase robustness and move away from straightforward 'copy-out'. ${ }^{35}$ Reform took over ten years but was finally realised in 2012 when the new procurement law, the Aanbestedingswet, was passed. The new Act has reordered provisions from the underlying procurement Directives so that they follow a typical procurement process timeline; it has brought together measures from all three Directives (including remedies) into one Act; and it has introduced new rules for public contracts below the EU value thresholds. Notwithstanding the concerns about transparency and collusion that led to reform, Van de Meent and Manunza have argued that 'the relevance of preventing and deterring bidder's collusion has not received the attention it should deserve in the legislative process leading to the [.] 2012 [Procurement Act]'. ${ }^{36}$

\footnotetext{
30 Article 8.3 Algemene Wet Bestuurrecht (Dutch General Administrative Law Act).

31 Https://www.pianoo.nl/public-procurement-in-the-netherlands.

32 Http://services.somo.nl/advice/public-procurement/.

33 Decree of 16 July 2005 ('Bao'), BAD 2005, 408 and Decree of 16 July 2005 ('Bass'), BAD 2005, 409.

34 See Tenders (EEC Regulations) Framework Act of 31 March 1993, Bulletin of Acts and Decrees (BAD) 1993, 212 and 213. Decree of 4 June 1993, BAD 1993, 305 and repealed by Decree of 16 July 2005, BAD 2005, 408 (Public Procurement Decree), Decree of 6 April 1993, BAD 1993, 214 and repealed by Decree of 16 July 2005, BAD 2005, 409 (Utilities Tendering Decree).

35 See, further, the proceedings of the Parliamentary Committee of Inquiry into the Construction Industry and A. Doree, 'Collusion in the Dutch Construction Industry: An Industrial Organization Perspective' Building Research \& Information (2004) 32(2), pp.146-156.

36 See J. Hebly, E. de Boer and F. Wilman, 'Rechtsbescherming bij aanbesteding' (Uitgeverij Paris, Zutphen, 2007) for critique of Dutch procurement law pre-reform in 2012, especially as regards judicial protection in the field.
} 
The 2012 Procurement Act entered into force on 1 April 2013. The Act is further detailed in the Public Procurement Decree (Aanbestedingsbesluit). This designates the Proportionality Guide (Proportionaliteitsgids) as mandatory guidance; noncompliance with which requires advance notice in tender documentation and justification ('comply or explain').

\subsubsection{Social Procurement: Law and Policy}

Dutch ambitions in the field of social procurement were kick-started in 2005 when, prompted by a parliamentary call to do so, the central government resolved to include sustainability criteria in all government procurement by 2010. Local and regional authorities followed suit and committed to make sustainability a priority, aiming for municipalities to achieve $75 \%$ sustainable procurement by 2010 and provinces and district water boards to achieve $50 \%$ by 2011 . Minimum sustainability criteria were drawn up by SenterNovem for 80 (later reduced to 45) procured product groups. These product groups cover the majority of purchases by the Dutch government. The focus is more on environmental than social sustainability, but many of the regulated products come from sectors in which there are known to be serious violations of international labour standards. ${ }^{37}$ The Criteria Document for each product group details ways in which sustainability can be addressed. Criteria Documents have been designed to be as practical as possible to enable sustainability requirements to be copied directly into tender documentation. ${ }^{38}$ The Netherlands is exceptional among EU states in prioritising particular product groups within its sustainable procurement policy. ${ }^{39}$

In 2012 the Dutch government supplemented its Criteria Documents by developing a set of 'Social Conditions'. Since 1 January 2013, the Social Conditions must be included in all central government tenders with values exceeding the EU threshold. The Social Conditions are based upon core ILO standards, including freedom of association and the right to organise, the abolition of forced and child labour, and the elimination of discrimination. They apply to all product groups and are contract performance clauses rather than criteria for selecting tenders. A manual for contracting authorities has been developed alongside the Conditions (Handleiding Social Voorwaarden). This sets out how contracting authorities should apply the Social Conditions. In April 2013 new guidance was implemented that made it standard practice in the Netherlands to select tenders on grounds of most economic advantage.

$37 \quad$ Stichting Onderzoek Multinationale Ondernemingen (SOMO) 'A Review of Dutch Policy for Socially Responsible Public Procurement', March 2014, p.2.

38 T. Padding, ' $100 \%$ ? Six years of sustainable procurement in the Netherlands': https://www.pianoo. $\mathrm{nl} /$ sites/default/files/documents/documents/sixyearsofsustainableprocurementinthenetherlands. pdf.

39 T. Bianchi and V. Guidi (eds.) 'The Comparative Survey on the National Public Procurement Systems Across the PPN', December 2010: www.ppneurope.org/docs/ItalianPresidency/Comparative\%20 survey\%20on\%20PP\%20systems\%20across\%20PPN.pdf. 
This adds further support to the government's focus on sustainability, as a component of quality, rather than on lowest cost.

The approach taken to social sustainability within the 2012 Procurement Act has been consistent with the ambitiousness of Dutch policy. One of the five generally applicable provisions of the 2012 Act is an obligation on contracting authorities to create as much societal value as possible in return for the sum paid by the state under the contract (maatschappelijke waarde). ${ }^{40}$ This is known as Social Return. A common example of Social Return in practice is that tenderers should spend a minimum percentage of the contract sum or contract staff wages on increasing employment among people who are long-term unemployed or disabled. The inclusion of a Social Return component is mandatory for national government contracts that have a value exceeding $€ 250,000$. Contracting authorities may include environmental and social goals within technical specifications ${ }^{41}$ and they must take account of sustainability requirements at all stages of procurement processes. ${ }^{42}$

In focusing upon the most economic advantage rather than cost, pursuing Social Return and enabling social and environmental policies to be considered at all stages of procurement processes, the Dutch Procurement Act of 2010 anticipated many of the reforms in the new 2014 EU procurement Directives. The Dutch government's view is that the new EU Directives may further facilitate social procurement by including market consultation and innovation partnerships (Article 31); two procedures that were already possible under the 2012 Dutch Act. Market consultation enables contracting authorities to inform businesses about procurement plans and needs before a procurement process begins. Innovation partnerships make it possible for contracting authorities to limit the number of candidates invited to tender in order to obtain an innovative product, work or service. The Dutch government also considers the possibility of granting preference to sheltered workshops as well as social businesses as aligned to emphasis within the 2012 Act on increasing the employment of disabled and disadvantaged people through the Social Return policy.

In June 2015 a draft reform proposal was submitted to the Council of Ministers. This was followed in September by submission to the Council of State and, on 29 October, to Parliament. Parliament has not yet approved the proposal but is expected to do so before the transposition deadline of 18 April 2016. ${ }^{43}$ The Dutch Prime Minister answered questions on the proposal in January 2016. ${ }^{44}$ PIANOo has produced a helpful summary of the key changes to the Dutch 2012 Act. ${ }^{45}$ No great change is expected to Dutch procurement law or policy as a result of the new general

\footnotetext{
$40 \quad$ Art 1.4(2) Public Procurement Act 2012.

41 Arts 2.75 and 2.76 Public Procurement Act 2012.

42 Arts 2.93, 2.114, 2.115, 2.80 and 2.82 Public Procurement Act 2012.

43 For the draft proposal see: https:/www.pianoo.nl/sites/default/files/documents/documents/ geconsolideerde-versiewetsvoorstelwijzigingaw2012.pdf.

44 Www.tweedekamer.nl/kamerstukken/wetsvoorstellen/detail?id=2015Z20333\&dossier=34329.

45 Https://www.pianoo.nl/document/11752/pianoo-overzicht-wijzigingen-aanbestedingswet-2012.
} 
procurement Directive: it is striking that only one of the five key changes to the 2012 Act follows directly from the new general procurement Directive. The 2012 Act and Dutch procurement policy has foreshadowed most reforms at EU level.

\subsubsection{Social Procurement: Practice}

What difference might the new EU Directive make to Dutch procurement practice? In short, the answer appears to be 'not much'. Although there is a lack of empirical evidence about how social procurement policies are being applied on the ground in the Netherlands, evidence suggests that compliance with existing social procurement policy is already fairly high among Dutch contracting authorities. A review of compliance undertaken for the Dutch government by KPMG, a firm of auditors, found that the Criteria Documents (for specified procured product groups) were followed by central government in $99.8 \%$ of purchases in $2010,95.8 \%$ by the Dutch provinces, and $85-90 \%$ by the municipalities. ${ }^{46}$ A European Commission-funded study of the strategic use of public procurement across the EU described the Netherlands as a 'front-runner' in the use of procurement to further social policy objectives, alongside the UK and Norway. The authors of this study for the Commission found that social procurement policies were used by over $40 \%$ of their Dutch contracting authority respondents; use was said to 'correspond noticeably' with levels of social procurement clauses that made it into tender documents. ${ }^{47}$ Van de Meent and Manunza point to Dutch case law to illustrate 'the prevalence of social return and life cycle costs in the process of public procurement'. They take the view that the Dutch courts are 'well aware of the importance of green public procurement' ${ }^{48}$ and consequently confine review of sustainability requirements to questions of transparency and equal treatment, rather than substantively evaluating the merits and scope of sustainability requirements. 49

More detailed, micro studies of procurement practice paint a more cautiously optimistic and geographically varied picture of social procurement in the Netherlands.

$46 \quad$ KPMG 'Monitor duurzaam inkopen 2010', 15 June 2011: www.denhaag.nl/en/residents/to/MonitorDuurzaam-Inkopen.htm.

47 W. Kahlenborn, C. Moser, J. Frijdal and M. Essig 'Strategic Use of Public Procurement in Europe', Final Report to the European Commission MARKT/2010/02/C.

48 G. van de Meent and E. Manna (ed.), 'The Netherlands' National report (XXVI FIDE Congress, Topic 3, The Netherlands), May 2014, p.26.

49 Darhuizer B.V. v. Boot \& Co Boomkwekerijen B.V. ECLI:NL:RBDOR:2010:BP0722 is cited as an example of this: http://uitspraken.rechtspraak.nl/inziendocument?id=ECLI:NL:RBDOR:2010: BP0722. This case concerned a challenge to the decision of several Dutch City Councils to award a contract to grow trees and bushes. The claimant argued that the contract should not have been awarded to his competitor because his competitor had not complied with with the sustainability requirement that $75 \%$ of the trees be grown in pots that do not stand against each other (so as to leave more space for the trees to grow, which should increase the quality of the trees). Though see also Advies 166, Commissie van Aanbestedingsexperts: https:/www.commissievanaanbestedingsexperts.nl/sites/ default/files/adviezen/141128\%20-\%20Advies\%20166.pdf. 
A review by SOMO of 25 tenders for coffee, natural stone, work clothing, and electronics, found that only three of those tenders referred to the Social Conditions. 12 tenders referred to working conditions, basic ILO standards or additional labour standards such as payment of the living wage. Ten tenders made no reference to social aspects at all. ${ }^{50}$ Although the review found one example of outstanding social procurement practice in a natural stone tender in Utrecht, it concluded that 'procurers are not yet sufficiently engaged with applying social criteria. ${ }^{51}$

The authors of the SOMO review suggest that the impediments to more ambitious social procurement in the Netherlands are partly legal, particularly in that the Netherlands has chosen to focus its social procurement efforts on particular product groups. ${ }^{52}$ However, most of the blockers identified in research are extralegal, arising because of the limitations in knowledge, capacity, monitoring and research with which procurement law is approached. Research by SOMO found, for example, that procurers 'do not have enough knowledge of adverse impacts in production chains and only look at whether bidders submit the requested documents. ${ }^{53}$ In 2011, Wouter Stolwijk, managing director of PIANOo, described the approach to procurement in the Netherlands as especially legalistic: 'nowhere do lawyers dominate the [procurement] debates as in NL'. ${ }^{54}$ This may be undermining commissioners' confidence and social policy creativity. Wouter Stolwijk has suggested that this also may be narrowing the field of market participants and thereby undermining competition. He has described highly relational and rather closed forms of procurement dealing in the Netherlands, preferring 'the same (small) set of suppliers'. This approach he said, 'is not formally legal in EU rules, but in most other cases it is still abundant'.

There appear to be some problems with Social Return from the perspective of small- and medium-sized enterprises (SMEs). In a study of best social procurement practice across Dutch municipalities, Oden and colleagues found that in some cases Social Return is preventing SME participation in procurement exercises. ${ }^{55}$ This is because it is not always possible for SME tenderers to satisfy Social Return requirements within the subject matter of the contract. Oden reports that SMEs often need opportunities to satisfy Social Return requirements in more creative ways by, for example, increasing the employment of disadvantaged people within their organisation but not within the part of the business to which the tender relates. This comes into conflict with procurement law requirements that social policy

\footnotetext{
50 SOMO, 'A Review of Dutch Policy for Socially Responsible Public Procurement', March 2014, p.6.

$51 \quad$ Ibid, p.9.

52 Ibid, p.10.

53 Ibid, p.9.

54 'Public Procurement in the Netherlands', presentation delivered in Budapest, November 2011.

55 P. Oden, 'SMEs Cooperate to Meet Social Procurement Conditions', Understanding Small Enterprises Conference 2015 - Proceedings, A Healthy Working Life in a Healthy Business 2123 October 2015, Groningen, The Netherlands.
} 
conditions relate only to the subject matter of the contract. ${ }^{56}$ Oden and colleagues also highlight 'crowding out' as a negative effect of social procurement. This describes the displacement of existing employees who work on the contract and their replacement with people who are currently unemployed. ${ }^{57}$ Dutch social procurement policies may therefore be having unwanted negative effects upon the number and types of business that are able to participate in procurement exercises. Moreover, some of the social benefits that appear to flow from social procurement policies may not be all that they seem; they may be leading to reallocations of benefit rather than the creation of new pro-social opportunities.

\subsection{UNITED KINGDOM}

\subsubsection{Overview of Sources and Legislation}

Although OECD data suggest that the UK spends less on procurement than the Netherlands as a percentage of GDP, in 2013-14 the UK public sector spent $£ 242$ billion (33\% of total public sector spending) on procuring goods and services. ${ }^{58}$ Responsibility for procurement policy, advice and direct buying sits with the Crown Commercial Service, within the Cabinet Office. Procurement opportunities and existing procurement contracts are published through an online portal called 'Contracts Finder' ${ }^{59}$ Unlike in the Netherlands there exists no dedicated procurement dispute resolution body; nor is there a specific social procurement advice body. Procurement is a mostly devolved power meaning that the Scottish Parliament takes its own decisions in this field, rather than deferring to Westminster. The Welsh Parliament also enjoys some competence in the procurement field, though more limited than its Scottish counterpart. ${ }^{60}$

The 2004 procurement Directives were implemented in England, Wales and Northern Ireland by way of the Public Contracts Regulations 2006. Unlike in the Netherlands the UK government did take a copy-out book approach, favouring instead to regulate (albeit in a more 'light touch' way) some procurement activities below the EU contract value threshold. In Scotland the general procurement Directive was implemented through the Public Contracts (Scotland) Regulations 2012.

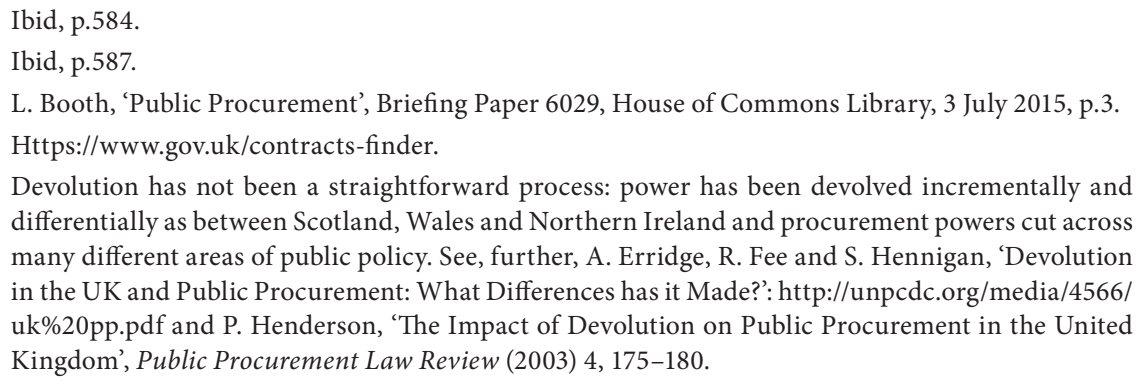
differentially as between Scotland, Wales and Northern Ireland and procurement powers cut across many different areas of public policy. See, further, A. Erridge, R. Fee and S. Hennigan, 'Devolution in the UK and Public Procurement: What Differences has it Made?': http://unpcdc.org/media/4566/ uk\%20pp.pdf and P. Henderson, 'The Impact of Devolution on Public Procurement in the United Kingdom', Public Procurement Law Review (2003) 4, 175-180. 
After the European Parliament passed the new package of procurement Directives, there was consultation across the UK about implementation. The Public Contracts Regulations 2015 came into force on 26 February 2015; the Westminster government having wanted to implement the new procurement Directives earlier than the deadline for transposition 'to take advantage of the new flexibilities as soon as possible'.61 The Regulations take a 'copy-out' approach to implementing the new general procurement Directive (2014/24/EU), though some specific local procurement rules are included for England, Wales, and to some extent, Northern Ireland. These specific local rules focus mostly upon simplification and improving the participation of small- and medium-sized enterprises (SMEs) within procurement processes. These focuses flow from evidence that a smaller percentage of SMEs take part in UK procurement processes compared to elsewhere in the EU, ${ }^{62}$ and that some of the barriers to participation include procurement processes being too time consuming or costly. ${ }^{63}$ The current British Conservative government has pledged to increase the percentage of government spending that is awarded to SMEs to a third. ${ }^{64}$

The Scottish government had already been developing its procurement law prior to the new Directives. The Procurement Reform (Scotland) Act 2014 received Royal Assent, on 17 June 2014. The 2014 Act creates a 'national legislative framework for sustainable public procurement', empowering Ministers to make Regulations and issue Statutory Guidance on a number of specified issues. ${ }^{65}$ As is explained on the Scottish government's website, the 2014 Act:

'centres on the Scottish Model of Procurement, which puts procurement at the heart of Scotland's economic recovery. It sees procurement as an integral part of policy development and service delivery. It is a simple concept - business friendly, socially responsible. Looking at outcomes not outputs, it uses the power of public spend to deliver genuine public value beyond simply cost/quality in purchasing. ${ }^{.66}$

61 Cabinet Office, 'Government Response to the Consultation on UK Transposition of new EU Procurement Directives', p.2: https://www.gov.uk/government/uploads/system/uploads/ attachment_data/file/400242/Government_Response_to_the_Consultation_on_UK_Transposi tion_of_new_EU_Procurement_Directives_Public_Contracts_Regulations_2015.pdf. European Commission, 2014 SBA [Small Business Act for Europe] Fact Sheet: United Kingdom (October 2014).

63 Federation of Small Businesses, Local Procurement: making the most of small business, one year on (June 2013).

64 Conservative Manifesto 2015: https://s3-eu-west-1.amazonaws.com/manifesto2015/Conservative Manifesto2015.pdf. See also HM Government, 'Consultation Document: Making public sector procurement more accessible to SMEs': https://www.gov.uk/government/uploads/system/uploads/ attachment_data/file/243685/SME_consultation_-_publication_version_-_18september.pdf.

65 See further www.scottish.parliament.uk/parliamentarybusiness/Bills/68170.aspx.

66 Www.gov.scot/Topics/Government/Procurement/policy/ProcurementReform/ProcReformAct. 
Scottish Ministers have committed to take a 'coordinated approach' to implementing the 2014 Act and the new procurement Directives. The Public Contracts (Scotland) Regulations 2015 were laid in the Scottish Parliament on 18 December 2015 and will come into effect on 18 April $2016 .{ }^{67}$

\subsubsection{Social Procurement: Law and Policy}

The UK is considered by many to be at the forefront of EU Member States in sustainable procurement. There is certainly a plethora of published guidance in the UK. Yet, while there are outstanding examples, such as the Greater London Authority's commitment to the Living Wage through procurement, most policy documents are complex and cautious in tone. ${ }^{68}$ They defer extensively to the European Commission's conservative Interpretative Communication, ${ }^{69}$ especially on the issue of social award criteria. ${ }^{70}$ Guidance is at its most ambitious in respect of equality issues. However, in February 2011, the Cabinet Office advised contracting authorities 'not [to] place disproportionate or unnecessary selection criteria or marking schemes including relating to equality, on economic operators'. In its 2007 report to the International Labour Organisation, the UK government evidenced a negative attitude towards social procurement, arguing that: 'The inclusion of labour clauses can add cost and bureaucracy to contracts, without any clear indication of benefits, and the contracting authority runs there risk of contravening EU rules. ${ }^{71}$ The benefits of what positive guidance exists about social procurement may be undermined by evidence that commissioners and contracting authorities find the policy guidance 'unhelpful and unclear'. ${ }^{72}$ In 2007, Brammer and Walker reported that ' 83 per cent of purchasing professionals considered themselves ill equipped to deliver sustainability through procurement. ${ }^{73}$

Perhaps the most positive development in England and Wales from a social procurement perspective has been the enactment of the Public Contracts (Social Value) Act 2012. The Social Value Act requires public authorities that are procuring services (but not goods or works) to consider how the proposed procurement might

67 For a summary of changes see 'Changes to the Procurement Rules in Scotland', Scottish Procurement Policy Note SPPN 6/2015, 18 December 2015: www.gov.scot/Resource/0049/00491432.pdf.

68 A. Ludlow, Privatising Public Prisons: Labour Law and the Public Procurement Process (Oxford: Hart, 2015), pp.136-141.

69 European Commission, 'Interpretative Communication on the Community law applicable to public procurement and the possibilities for integrating social considerations into public procurement' COM (2001) 566 final.

70 See e.g. Office of Government Commerce, Social Issues in Purchasing (OGC: London, 2006) and Buy and Make a Difference: How to Address Social Issues in Public Procurement (OGC: London, 2008).

71 UK Government report to the ILO (2007).

72 E. Aspey 'Labour considerations in EU procurement: a study of UK utilities' European Law Review (2012) 37(3), 294.

73 S. Brammer and H. Walker 'Sustainable procurement practice in the public sector: an international comparative study', University of Bath School of Management Working Paper Series 16, (2007), p.9. 
improve the economic, social and environmental well-being of their area. The Act applies to England and, to a more limited extent, also to Wales. It is weaker than the Dutch Social Return obligation because it is satisfied so long as contracting authorities have regard to economic, social and environmental well-being; no specific action other than consideration is required under the Act. Two years since the enactment of the Social Value Act, Lord Young reviewed awareness of the Act, its use and impact. Although he found that the Act had positive effects where it had been taken up, the predominant finding of the Review was that incorporation of social value in actual procurements appears to be relatively low when considered against the number and value of procurements across the whole public sector. ${ }^{74}$ Lord Young also identified misunderstanding about the Act among commissioners and bidders. These misunderstandings were leading to inconsistent practices and, in some cases, improper application of the Act. The Social Value Act

Following implementation of the new procurement rules through the Public Contracts Regulations 2015, updated guidance on social procurement is still awaited from the Cabinet Office. By comparison with what the Scottish government has communicated about its implementation of the new procurement Directives, it is clear that social procurement is less of a policy priority for Westminster than it is in Edinburgh. Scottish implementation of the new general procurement Directive has strongly emphasised the social policy dimensions. The Scottish government's policy note that accompanies the draft Public Contracts (Scotland) Regulations 2015 highlights how discretion is being exercised to provide strong support for a social procurement agenda within the new rules. Blacklisting of workers, for example, is described in the policy note as 'an unacceptable practice' with the consequence that the Scottish government 'has decided to use the flexibility offered by the public procurement Directive to make it mandatory for contracting authorities to exclude businesses from procurement exercises which have been found to have committed [blacklisting]'. ${ }^{75}$ On 6 October 2015 the Scottish government published statutory guidance on fair work practices in procurement, including payment of the Living Wage. As is described on the Scottish government's website:

'The guidance makes clear that the Scottish Government considers payment of the Living Wage to be a significant indicator of an employer's commitment to fair work practices and that the payment of the Living Wage is one of the clearest ways that an employer can demonstrate that it takes a positive approach to its workforce. ${ }^{76}$

Although The Social Value Act has given new vitality and presence to social procurement within the Cabinet Office, Westminster social procurement policy

\footnotetext{
$74 \quad$ Cabinet Office, 'Social Value Act Review', February 2015, p.4.

75 'Changes to the Procurement Rules in Scotland', Scottish Procurement Policy Note SPPN 6/2015, 18 December 2015, p.4: www.gov.scot/Resource/0049/00491432.pdf.

76 Www.gov.scot/Publications/2015/10/2086.
} 
continues to be more measured and conservative in its tone than Scottish Government policy. It seems unlikely that this will change as a consequence of the new procurement Directives.

\subsubsection{Social Procurement: Practice}

As Barnard has argued, citing the failure to deliver a living wage for all those who worked on the London Olympic sites: 'Rhetorical commitment is one thing, application is another.' ${ }^{77}$ A theme that is common to the UK and Netherlands is the dearth of empirical evidence about public procurement: there are few studies of procurement law in practice; fewer still looking at motivations for, approaches to, and impacts of, social procurement practices. However, what is clear from the UK literature, perhaps more than it is in the Dutch literature, is that the contracting out of services in the UK has had adverse impacts on the workforce, particularly in some sectors. ${ }^{78}$ Most modestly put, this might suggest that if the UK has a strong policy commitment to social procurement, contracting authorities are not succeeding in putting it into practice. Conversely, and more provocatively, there is evidence in some sectors, such as prisons, that contracting out has been used explicitly as a tool to 'create new flexibility' by undermining labour standards, rather than promoting or enhancing social policy objectives. ${ }^{79}$

The introduction of the Social Value Act has somewhat changed this narrative in favour of procurement practices that are more pro-social. The Crown Commercial Service has created Social Value Awards 'to recognise and celebrate good practice in commissioning and providing social value'. Social procurement case studies have been included on the Crown Commercial Service's website. ${ }^{80}$ It is clear from these, and other, case studies, that some businesses are councils are taking innovative approaches to social procurement. In May 2015, for example, Network Rail launched a Code of Conduct for Labour that sets out minimum standards in respect of working practices that any suppliers must achieve. Network Rail has also implemented the London Living Wage across its procurement, focusing especially upon typically lowwage areas such as contingent labour and soft facilities management contracts for

77 C. Barnard, 'Procurement Law to Enforce Labour Standards' in G. Davidov and B. Langille (eds.), The Idea of Labour Law (Oxford: OUP, 2011), p.271.

78 See, e.g., National Audit Office (NAO), Protecting Staff in PPP/PFI Deals (London: NAO, 2008), T. Colling and A. Ferner, 'Privatisation and Marketization' in P. Edwards (ed.), Industrial Relations: Theory and Practice in Britain (Oxford: Blackwell, 1995); T. Colling, 'Contracting public services: the management of compulsory competitive tendering in two county councils' (1993) 3(4) Human Resource Management Journal 1 and Public Services Privatisation Unit, Privatisation: Disaster for Quality (London: Public Services Privatisation Unit, 1992).

79 A. Ludlow, 'Competition and Contestability in Action: Restructuring the Prison Sector to Achieve Workforce and Industrial Change’ (2012) 3 Public Law 508-526.

80 Https:/www.gov.uk/government/publications/social-value-act-information-and-resources/socialvalue-act-information-and-resources. 
cleaning, security and waste management services. Following the Social Value Act, Network Rail included social procurement response requirements in a recent tender for the management of lineside vegetation. The company has moved away from nil value framework contracts to framework contracts that guarantee a level of spend so as to discourage the use of zero-hours contracts. ${ }^{81}$

Yet, notwithstanding these positive examples, evidence of social procurement practices remains rather limited in the UK. It may be that good practice keeps a low profile because of some nervousness and fear of litigation among contracting authorities. Procurement mistakes are costly, both in financial and reputational terms: processes have to be repeated, damages have to paid, and signals are sent out to the market that undermine perceptions of the commissioner's competence. ${ }^{82}$ However, Lord Young's Review of the Social Value Act suggests that there is in fact a problem in practice and that there are many examples of contracts that have been commissioned with little thought for social policy. The privatisation of probation services is a recent and particularly high profile example of this. ${ }^{83}$

\section{CONCLUSION}

These case studies of public procurement in the Netherlands and the UK lead to some valuable reflections upon the nature of EU law and its operation and absorption within varied national contexts, as well as the relationship between the EU and its Member States. They challenge a straightforward account of EU supremacy: that of straightforward obedience and subordination on the part of the Member States, and of uniform and deep penetration of EU law. It is clear from this small scale comparison of two Member States that the enactment of a common legal signal, through the new procurement Directives, has not been 'heard' in the same way and maps onto very different pre-existing contexts. The Netherlands had already anticipated the EU's direction of travel in favour of social procurement. The UK has chosen to focus on the 'flexibilities' within the new procurement rules to further a national agenda of simplification and increasing the participation of SMEs. What Westminster has not said about social procurement becomes even more telling by comparison with

81 Presentation by Tony Winn, Senior Procurement, Network Rail, 'Procurement and Precarity' conference, Trinity College, Cambridge, 14 May 2015.

82 For example, in 2012, the Department for Transport had to cancel the franchise process for the West Coast Main Line after the discovery of 'significant technical flaws' in the process. The process was aborted because Virgin launched a judicial review of the decision to award the contract to FirstGroup. Two independent reviews followed. See, further, https://www.gov.uk/government/ news/west-coast-main-line-franchise-competition-cancelled and www.theguardian.com/publicleaders-network/2012/oct/03/west-coast-rail-fiasco-procurement.

83 See, e.g, www.theguardian.com/society/2015/mar/30/probation-officers-face-redundancy-inplan-to-replace-them-with-machines and www.theguardian.com/public-leaders-network/2015/ apr/09/probation-service-split-staff-demoralised-divided-private-services. 
the volume and visibility of what has been said about social procurement by other governments. These case studies also highlight important differences in how the new procurement rules have been received at the sub-national level, as, for example, between England and Scotland. There is, perhaps, a need for more research that connects the macro, meso and micro to shed light light upon the relationships and dynamics that exist between and within these different actors and institutions.

These case studies also remind us of law's dynamism and the constant mutual evolution of law at EU and national levels. That the Netherlands, and to some extent Scotland, anticipated in their law and policy a more generous approach to social procurement, highlights the diffuse and subtle nature of power and influence within the EU. The sincere cooperation of Member States with the EU does not imply a 'start-stop' account of legal change as between the EU and the Member States or a straightforward powerful versus powerless binary. Procurement provides a very good example of how the EU harnesses its momentum from the collective energies of the Member State. In many fields, the EU and its Member States make progress in tandem and through complex and interwoven forms of coproduction. The processes of transposing EU law into national legal systems are intimately intertwined with national negotiating positions and pre-existing and other broader national policy objectives. Seen in this way, these case studies tend to affirm Directives as legal tools that incorporate meaningful notions of subsidiarity: they can and do, in practice, make space for national agendas and priorities. This does, of course, also mean that in cases where Member States are less persuaded about the benefits of a given EU direction of travel, as is perhaps the case with social procurement in England and Wales, they can choose to minimally implement the relevant rules, or pursue alternative agendas in their policies that diminish or even conflict with the EU's agenda.

What, then, are the prospects for social procurement following transposition of the new Directives across the EU? Given that the date for transposing the Directives into national law has not yet passed, this is a story that is still unfolding. However, the accounts of how the Netherlands and the UK are thinking about, and implementing, the new procurement rules suggest that uptake of social procurement will continue to be patchy both between and within Member States. Member States that wish to pursue an ambitious social policy agenda through procurement may gain confidence from the reforms at EU level. However, the anticipatory nature of social procurement agendas in the Netherlands and Scotland might suggest that EU law reform will bring about fewer direct changes in this field than we imagine: those Member States who are strongly committed to social procurement may pursue those policies without too much concern for EU law constraints or enablers.

The procurement field reminds us of the importance of 'soft' law and nonlegal factors, such as knowledge, capacity, vision and commissioning expertise, in shaping practice. There is evidence from both the Netherlands and the UK that these factors play a critical role in how procurement law is translated into practice and there is evidence that policy can be more important than 'hard' law in steering 
the procurement decision-making of contracting authorities. In one sense then, the formal legal position reflected in Directives may be less important than the pro-social signals that could be communicated through confident and clear guidance from the European Commission and national institutions and from practical initiatives such as building repositories of good social procurement practice, and facilitating cross-sector dialogue and learning between procurement practitioners beyond national frontiers. If the EU is truly committed to unlocking the pro-social potential of procurement, the case studies presented in this paper suggest that the EU may need to re-focus its efforts away from legal reforms towards empowering, capacitating and awakening the social policy imaginations of contracting authorities. 